\title{
Co-constructing principles for Digital Farmer Field School Enrekang Design in South Sulawesi - Indonesia
}

\author{
Nurdahalia Lairing ${ }^{1 *}$, Loes Witteveen ${ }^{2 *}$,Yunus Busa ${ }^{1}$, Arsil Bagenda ${ }^{3}$, Mursalim Bagenda ${ }^{4}$, \\ and $A d d i^{5}$ \\ ${ }^{1}$ Research Centre for Communication, Social Ecological Learning, and Sustainable Environment, \\ University of Muhammadiyah Enrekang, South Sulawesi - Indonesia. \\ ${ }^{2}$ Research Group for Communication, Participation and Social Ecological Learning, Van Hall \\ Larenstein - The University of Applied Sciences, The Netherlands. \\ ${ }^{3}$ District Livestock and Fisheries Office, Enrekang District, South Sulawesi - Indonesia. \\ ${ }^{4}$ District Environment Office, Enrekang District, South Sulawesi - Indonesia. \\ ${ }^{5}$ District Agriculture Office, Enrekang District, South Sulawesi - Indonesia.
}

\begin{abstract}
Considering the challenges on sustainable agriculture in the district, different institutions join hands to overcome these issues and respond to the felt need of working more integrative both in the agricultural sector and environmental knowledge system. Adding a sense of urgency due to COVID-19 into problem analysis, these institutions accelerated the ambition to develop a Digital Farmer Field School (DFFS). This paper elaborates on the co-construction of principles for the design of a Digital Farmer Field School (DFFS) by the local stakeholders in Enrekang district. The local design team design of the DFFS Enrekang is composed of a transdisciplinary team from relevant government institutions and research institutions. The design principles of DFFS are built around inclusive design principles, concepts of interface usability based on different type of access to digital technology models, responsible innovation criteria and learning principles of farmer field school (FFS). The DFFS Enrekang design principles serve as guiding principles and shared value among the collaborating institutions to combine ambition, inspiration, and accountability in the DFFS management and development processes. This tablet based digital learning platform aims to provide an alternative for farmers to access information on sustainable agricultural and environmental practices.
\end{abstract}

\section{Introduction}

Exploring the sustainable agriculture pathways in Enrekang district, the local government collaborates with researchers from inside and outside the country. In 2018, the government invited University of Muhammadiyah Enrekang (UNIMEN) together with Van Hall

\footnotetext{
* Corresponding author: Nurdahalia Lairing : lialairing@unimen.ac.id, nurdahlia lairing@yahoo.com, Loes Witteveen : loes.witteveen@hvhl.nl
} 
Larenstein, the university of applied sciences, the Netherlands, to assess the agricultural situation and explore innovative approaches to engage farmers in local innovation. The results of the assessment [1] show that agricultural development in Enrekang district faces a complex array of challenges in increasing agricultural production without destroying the environment. Fears of loss of production due to disease and pest have forced farmers to use pesticides excessively. Also, the limited understanding of soil ecology have led the farmers to apply chemical fertilizers excessively. This has led to the degradation of land and water resources resulting in decreased levels of fertility and environmental pollution and combined with other environmental issues such as deforestation.

The limited systemic conceptualisation of these problems by the rural communities are, amongst others, resulting from limited access to information and ineffective rural communication services. Farmers need exposure to communication platforms and access to up-to-date information on different techniques and technologies for increasing productivity and diversifying into more commercial crops, real-time weather reports, cropping patterns, and soil and water management to cope with climate variability to name a few themes.

Amplifying the production chain, farmers need information on technology for crop and food storage and processing to add value to their raw produce, and marketing linkages to maximize profitability. Farmers also search to gain insights on environmental sound practices as they observe landslides, river pollution and question health impact of fertilizers and pesticides. All these mentioned topics feature on the agenda of the different institutions who are active in rural Enrekang while facing problems of mobility, staff training, communication and other scarce resources which inhibit realising well established goals in terms of extension, communication and farmer learning oriented activities. In addition, involved institutions realise that an inter-institutional approach towards social-ecological learning will pay justice to the systemic aspects of the issues at stake and optimise the use of the institutional resources.

The situation described above have led the local government and the different institutions of agriculture, livestock and fisheries offices, and environment office together with the local educational institute UNIMEN to explore how to overcome the disconnection between rural development policies and governance versus the implementation of the agricultural and environmental knowledge systems. When adding a sense of urgency due to COVID-19 pandemic to the problem analysis, these activities resulted in the plan to develop a Digital Farmer Field School (DFFS). DFFS is a tablet-based digital learning environment for farmers and other stakeholders in the rural knowledge system [2] providing an up-to-date communication platform, rural services, and information as an alternative and complementary system to conventional rural extension service. The DFFS is anticipated as one of the rural innovations that can mitigate the difficulties of extension officers traveling to visit the farmer groups in remote areas an insufficient number of extension workers to assist the farmer groups and to overcome the disconnect between agricultural and environmental issues.

The initiative of design and developing DFFS Enrekang was inspired by the DFFS Sierra Leone which was developed as an alternative to farmers certification training in the context of Ebola Epidemic where people restricted to conduct face to face meeting. With the pandemic of COVID-19, the design and development of DFFS Enrekang has become increasingly relevant and urgent. The application of social restrictions to suppress the transmission of COVID-19 has an impact on farmer extension activities that involves many people. In addition, the marketing of the agriculture products and the distribution of agriculture supplies were disrupted due to restrictions on the movement of people. Farmers need a new way to obtain information and market their agricultural products while government staff seeks to establish relevant and effective communication system with the rural communities. DFFS is considered as potential contributors to agricultural knowledge 
and extension system in times of Corona and beyond. It provides opportunity for farmers to use a more pro-active approach in the communication with the extension service and to use digital ways of monitoring pests, diseases and other events using visual methods. DFFS is conceived as a transformative innovation that will provide a platform to share, create, collect, and communicate knowledge surrounded by a restructured governance system of diverse institutional policies and services. With DFFS, farmers can access information more flexibly.

Since the introduction of DFFS in Enrekang district, series of activities related to setting up the foundation of the design and development of DFFS have been conducted. Part of these foundational activities, the local government established a DFFS project management team and a design team in 2019. The management team consists of decision makers from key stakeholders who are responsible to provide strategic directions and leadership for the DFFS project implementation, whilst the design team represents the DFFS key stakeholders' technical staff who are responsible for design, development, implementation, and maintenance of DFFS interface. The DFFS team are working in a Living Lab approach, working collaboratively to produce DFFS outcomes. Prior to the implementation of the DFFS project, these teams are provided with a training to equip them with knowledge and skills required for the development and implementing the DFFS in the district.

In January 2021, the regent of Enrekang officially launched the DFFS which marked the start of the design processes of the DFFS Enrekang. At the time of writing this paper, the DFFS design process is ongoing in conjunction with training for the local design team. The DFFS design process is still at the early stage; the local design team is gaining experiences to explore and analyse users' problems, needs and expectations which contributed to the process of constructing the design principles of DFFS Enrekang. This team seeks to elaborate a framework for the design and development of DFFS Enrekang including defining design principles to which designers and developer should adhere. The design principles aimed to provide input and guide the development of DFFS user interface. The design principles are generally adapted from pre existing DFFS in Sierra Leone with additions to specific aspects considering the local conditions and its users.

This paper elaborates the experiences of the key stakeholders in co-constructing the design principles the DFFS Enrekang. The paper starts with the background to the DFFS in Enrekang to give a full detail of the context which is required to come to grips with the originality and seriousness of the design and development of the DFFS Enrekang, including the current impact of the COVID-19 on agriculture extension and environmental communication activities. To bring the inter-institutional context of the DFFS initiative into motion, the design and development of DFFS Enrekang adopts a Living Lab approach as presented in the following section.

The process of constructing the design principles of DFFS Enrekang and the application of these principles in the design process so far are presented in a iterative perspective. The DFFS design team explored and developed the DFFS Enrekang design principles to formalize the accountability towards the end-users, ensuring that the implementation of a DFFS will benefit the farmers and the rural communication system at large facilitating knowledge creation and exchange.

\section{Living lab approach}

Rural development in Enrekang district faces a dilemma of increasing agricultural production without damaging the ecosystem. The local government considers this as a complex issue which requires an interdisciplinary perspective on the rural economy balancing agricultural production with environmental management and public health protection. To bring the DFFS key partners together in a new configuration of collaboration the local government actively supported to adopt a Living Lab approach in DFFS design and development. 
The initiation of a Living Lab approach of DFFS Enrekang aimed to bring all relevant stakeholders together and facilitate communication and working more integrative looking for a local innovation to overcome the challenges mentioned above. The Living Lab of DFFS Enrekang involves District Agriculture Office (DAO), District Livestock and Fisheries Office (DLFO), District Environment Office (DEO), District Health Office (DHO) and the Muhammadiyah University of Enrekang (UNIMEN) in close cooperation with the Dutch partner Van Hall Larenstein University (VHL).

Adopting a Living Lab approach has been welcomed by the partners as they gained confidence that their collaboration is in line with development strategies of Enrekang district and recognizing the conceptual approach for its contemporary values. This collaboration setting is an outstanding approach in the Indonesian context as it combines the strengths of educational and research institutions from Indonesia and the Netherlands in collaboration with rural communities, and governments. These key Living Lab partners are involved in the whole process of design, development and implementation of the DFFS as well as construction the design principles of DFFS Enrekang based on local condition and the need of the DFFS main users. The Living Lab approach is commonly acknowledged in the scientific literature as an important approach to discussing the strategic directions, assessing the implications and consequences of innovations and setting priorities and strategic choices in the design and development of an innovation $[3,4,5,6]$.

The combination of several institutes in Enrekang district is needed as a pillar to strengthen the empowerment of the governance system to sustainable agriculture. To make the living lab approach operational, a management and coordination team was formed by the decision makers from key stakeholders including the head of District Agriculture Office, the head of Agriculture Extension Division, the head of District Environment Office, the head of District Livestock and Fisheries office, and the rector of UNIMEN. This high-level team is responsible to provide strategic directions, decision making as well as financial plan to support the sustainability of DFFS in Enrekang. A design team was formed by 20 technical staff from key DFFS stakeholders. The design team is responsible to guide the process for designing, developing and managing the DFFS. As farmers groups are envisioned as the primary end users of DFFS a diversity of farmer groups have been actively involved in the process of DFFS design to ensure that their needs and aspirations are considered in the interface design. The different governance and knowledge institutions will intensify this cooperation with a focus on farmers groups as partners in the Living Lab during the prototyping stage of the DFFS.

\section{Co-construction approach}

The DFFS is a learning platform to be used by farmer groups and the rural (extension) officers for information sharing. The process of DFFS design and development is a learning process for the design team with different knowledge background and experiences. According to Jocelyn Nuttal [7] co-construction is a learning approach that involves a collaborative process in which learners learn from one another to further expand their knowledge.

Co-construction in this paper refers as the joint creation and interpretation of the design principles as an identity and guidance for the development of DFFS Enrekang. The co-prefix in co-construction is intended to cover a range of interactional processes, including collaboration, cooperation, and coordination among stakeholders involved in the DFFS. The DFFS team worked on a variety of assignments to search and define for new design principles or adapt the existing ones into the local context based on the result of a social ecological system analysis and users' needs exploration in rural Enrekang. It involved series of collaborative works, consultations, and documentation activities by small groups of diverse inter-institutional compositions to achieve optimal exchange of experiences, knowledges and 
relations with rural communities. The social-ecological system analysis resulted in a DFFS baseline report followed by user stories guide book and a seasonal calendar. As the construction of the design principles used (international) literature study and field research the results were documented in Bahasa Indonesia and English language; visual documentation was added to act on aspects as literacy and attractiveness. See figure 1 for a sketch reflecting ideas for the DFFS opening screen.

The combined process of design training, exploration and documentation provided opportunities for the design team to reflect on existing knowledges, to learn from each other and expand their knowledge in a cooperative setting which enabled gaining confidence on the added value of the Living Lab partnerships. The prevailing context of the Corona pandemic imposed using a different scheme to shape the training and all the exploratory activities over a longer period and with more diverse methods as originally foreseen. It still remains to be determined but the apparent 'slowness' might eventually be an asset to the development of DFFS Enrekang. Defying the challenges, using amongst others Zoom and Skype sessions, WhatsApp groups, on campus encounters, phone calls and fieldtrips (though limited but thereby appreciated) over a longer period of time, required more attention and made the process intensive but definitely enhanced a shared appropriation of the DFFS Enrekang ambitions by the Living Lab partners.

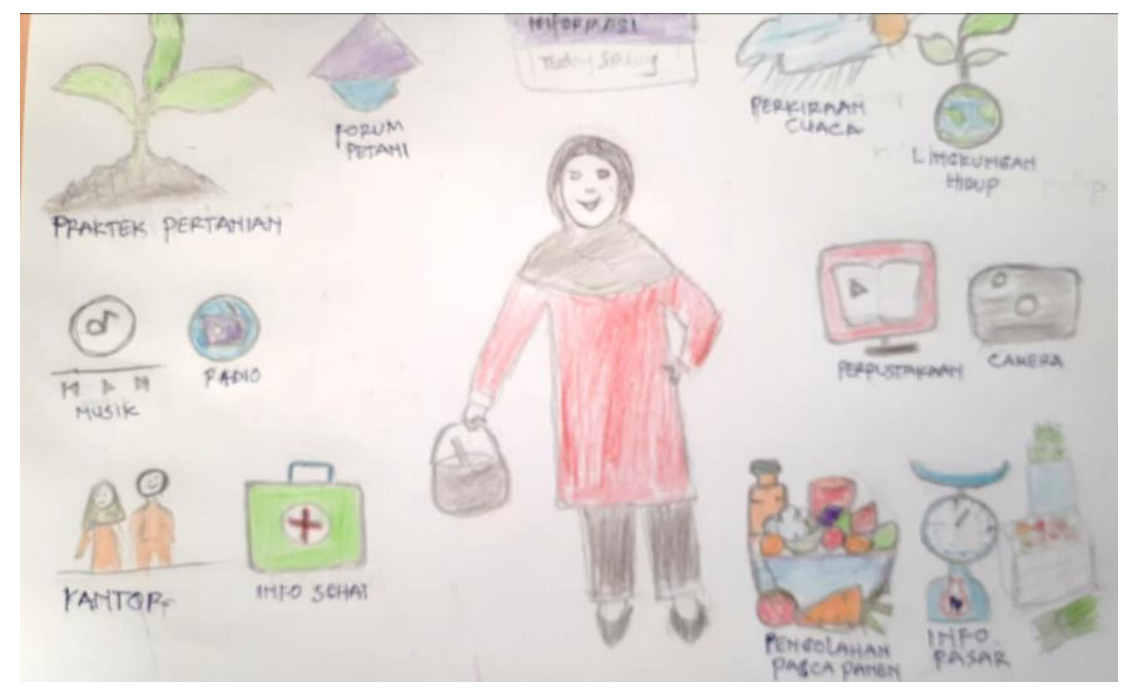

Fig. 1. Sketch of DFFS opening screen reflects draft ideas for DFFS Enrekang.

\section{DFFS Enrekang's design principles}

The process of constructing of the design principles for DFFS Enrekang was initiated during the training of 'Local Capacity Building in the Design and Development of DFFS' in which the DFFS Enrekang design and managements teams participated. The process of constructing these design principles for the context of Enrekang district aimed to come to grips with major aspects that will guide the design and the development process of DFFS. The design principles should provide a framework to continuously steer all operational activities towards the major envisioned impact of the DFFS. The design principles of DFFS Enrekang were inspired by the design principles elaborated for DFFS Sierra Leone and Mongolia which were then tailored to the local context of Enrekang. 
The design principles are constructed around the following elements:

\subsection{Farmer Field School (FFS) approach}

DFFS is a rural communication service that provides a relevant knowledge system materialised in a digital interface. The DFFS is inspired by FFS learning principles [8] operationalised in a digital approach. The DFFS should be focused to support farmer groups by promoting good agricultural practices, including integrated crop and pest management. DFFS is a tablet-based learning environment that will provide opportunities for group learning and activities. Farmers in Enrekang are grouped based on a crop or physical proximity of their farms. Given that the farmers manage several types of farming business, it is anticipated that the DFFS should be able to support diverse aspect in the value chains. See figure 2 for a representation of the DFFS as used by a mixed farmer group with male and female farmers.

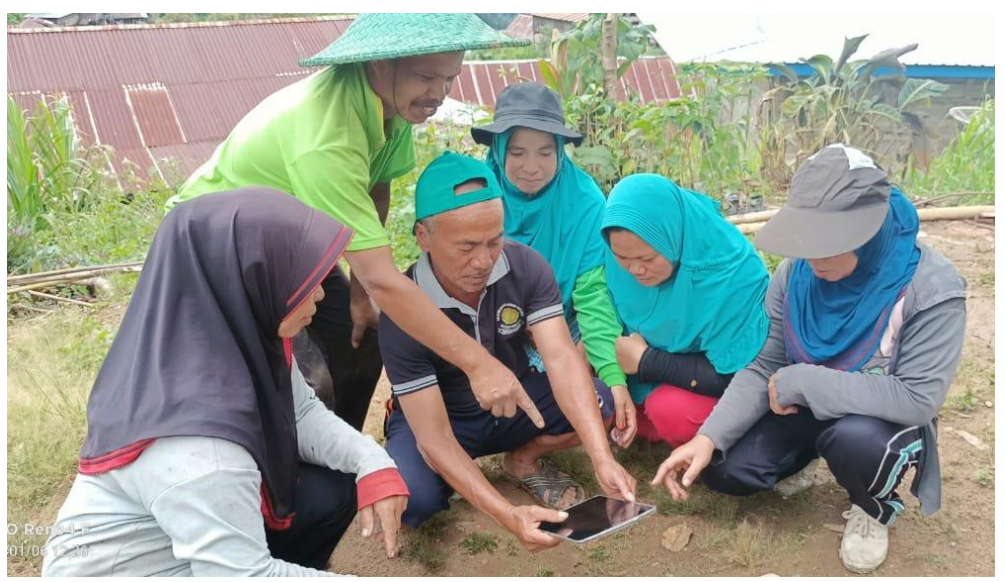

Fig. 2. The tablet based DFFS should be able to facilitate group learnings and collective actions and observation of events on farm.

\subsection{Response to COVID-19 pandemic}

In response to COVID-19 pandemic, the DFFS provides access to public health information that will support farmers and their family to take informed decision to prevent and control the spreading of COVID-19 virus. The DFFS can be an alternative reliable information source in relation to COVID-19, so that farmers are not exposed to inaccurate information that can lead to public anxiety.

\subsection{Interface usability}

A design principle on interface usability was formulated based on Van Dijk's digital technology model [9], [10]. The model focuses on four types of access: motivation to use digital technology, possession of smartphones and network coverage, skill access and usage access. In the context of Enrekang district, a large majority of farmers have reliable access to the phone connection and use it daily. Around two-thirds of the farmers use smartphones and are active on social media. Even those with limited network coverage, they use their smartphone for taking pictures and listening music while working in the farm. While general 
digital adoption is high especially amongst young farmers, farmers are not yet maximizing the use of technologies for business value. Most farmers still rely on agriculture extension officers, networks of peers, family or friends for agricultural information. With high exposure to the digital technology, the DFFS interface should be able to enhance the motivation of farmers and extension agents to use the DFFS. The design of the user interface should be user friendly allowing the farmers to explore, access and navigate the interface, or to share their concerns and questions with staff using the DFFS interface. On the other hand, the service providers (extension officers) are also able to await and respond to farmers queries through messages or calls from the back office, while having skills on managing and producing content for the DFFS.

\subsection{Responsible innovation aspects}

The design and development of DFFS Enrekang is being framed as to comply with four dimensions of responsible innovation framework [11] from the perspective of anticipation, reflexivity, inclusion, and responsiveness. The authors define responsible innovation as an effort of taking care of the future through collective action in the management of innovation in the presents". The following four dimensions of the responsible innovation criteria are agreed to be adapted into DFFS Enrekang:

- Aligned with the dimension of anticipation, the DFFS interface aims to provide access to training on good agricultural practices, including integrated crop and pest management in times of COVID-19 and beyond. The DFFS is foreseen to overcome difficulties of staff traveling to remote areas in Enrekang and provide relevant extension services to rural farmer groups.

- Aligned with the dimension of reflexivity, the design team agreed that the DFFS interface development is continuously shared and consulted with envisioned users and not further developed if relevance and feasibility are low. Involving farmers as the main users in all DFFS development processes is a promise that was articulated at the launching of DFFS.

- Aligned with the dimension of inclusion, the interface design recognizes the diversity of its end users in the diverse framer groups and other stakeholders. The DFFS should be able to attract young farmers but at the same time is accessible by the old one with low literacy skills. DFFS also provide equal opportunity to women and men for example by considering different time preferences in accessing the DFFS.

- Aligned with the dimension of responsiveness, the interface development appreciates diverse actor groups and is attentive to the creation of new interdependencies and agendasetting mechanisms, also recognising the demands for involved staff and institutional inflexibility.

\subsection{DFFS Ethical Standard}

In addition to the generic design principles outlined above the local team of DFFS Enrekang have also defined the DFFS ethical standard which was articulated as "we do not want to disappoint farmers" during an management meeting in November 2019, see figure 3. It's a guiding principle that governs the decision, action and behaviour of those involve in the design, development and management of DFFS ensuring that it truly benefit the end users. This requires the development process to be done carefully and withstand a sense of being hasty. As part of fulfilling this promise to the farmers, all parties involved in the DFFS project signed a confidentially agreement and research ethics [12] which binds them to uphold honesty, integrity, transparency, respect for human rights, respect for confidentiality, and responsibility for data and research results. 


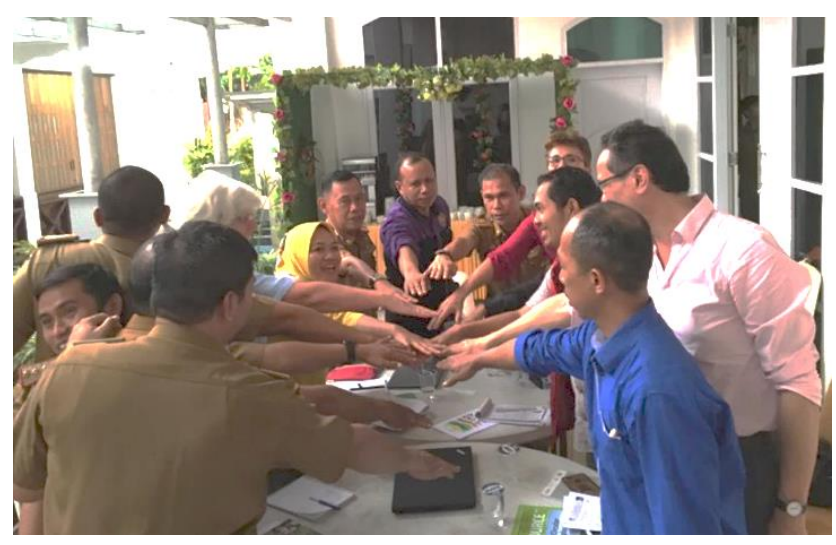

Fig. 3. The DFFS Enrekang team agreed on DFFS Ethical Standard in 2019.

\section{Conclusion}

The co-construction of DFFS design principles provided opportunities for the design team to practice the Living Lab approach as they exchanged knowledge and strengthened the collaboration among the stakeholders. The series of assignments effectuated to practice training elements in the Living Lab configuration, in direct consultation with the farmers as end-users, contributed to rethinking conventional practices in the rural knowledge system.

The obtained experiences directedly contributed to enhanced motivation of field officers for establishing innovative rural communication practices. The agreed design principles of DFFS Enrekang place the best interest of the farmers and recognise the challenges for extension officers which are built around inclusive design principles, interface usability based on different type of access to digital technology models, responsible innovation criteria and learning principles of farmer field school (FFS). DFFS design principles serve as guiding principles and shared value among the collaborating institution to combine ambition, inspiration, and accountability in the management and development processes of DFFS Enrekang.

\section{References}

1. N. Lairing and L. Witteveen, “Assessment Report. The project of Design and Development of a Digital Farmer Field School for Coffee Value Chain in Enrekang District, South Sulawesi - Indonesia," (2018)

2. L. Witteveen Loes, Margriet Goris, Rico Lie, A digital farmer field school for training in cocoa production and certification in Sierra Leone, no. April. (2016)

3. V. Blok, L. Hoffmans, and E. F. M. Wubben, J. Chain Netw. Sci., vol. 15, no. 2, pp. 147-164, (2015)

4. A. Delgado, K. Lein Kjølberg, and F. Wickson, Public Underst. Sci., vol. 20, no. 6, pp. 826-845, May (2010)

5. J. Stilgoe, R. Owen, and P. Macnaghten, Res. Policy, (2013)

6. J. Phillipson, P. Lowe, A. Proctor, and E. Ruto, J. Environ. Manage., vol. 95, no. 1, pp. $56-65,(2012)$

7. J. Nuttall, Int. J. Early Years Educ., vol. 11, no. 1, pp. 23-31, Mar. (2003)

8. FAO, "Farmer Field School Implementation guide. Farm Forestry and Livelihood Development," (2011)

9. J. A. G. M. van Dijk, The deepening divide: Inequality in the information society. SAGE Publications Inc., (2005) 
10. A. J. A. M. van Deursen and J. A. G. M. van Dijk, Gov. Inf. Q., vol. 26, no. 2, pp. 333340, (2009)

11. R. Owen, J. Stilgoe, P. Macnaghten, M. Gorman, E. Fisher, and D. Guston, Responsible Innov. Manag. Responsible Emerg. Sci. Innov. Soc., no. April, pp. 27-50, (2013)

12. R. Lie and L. Witteveen, J. Soc. Res. Methodol., vol. 20, no. 1, pp. 63-75, (2017) 